\title{
An agricultural sector assessment of biological asset valuation challenges with inputs considered from valuers
}

\section{Marilene van Biljon $^{1 *}$, Christa Wingard ${ }^{2}$}

Eastern Cape Rural Development Agency; Department of Financial Accounting, University of South Africa ${ }^{1}$ Department of Financial Accounting, University of South Africa ${ }^{2}$

marilenevanbiljon@gmail.com ${ }^{*}$,wingahc@unisa.ac.za

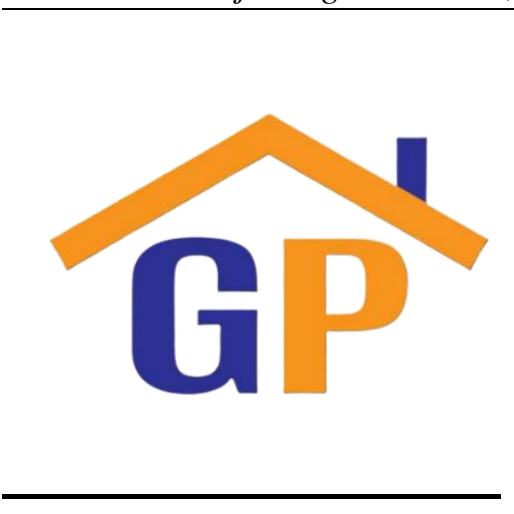

Article History

Received on 30 September 2020

$1^{\text {st }}$ Revision on 1 October 2020

$2^{\text {nd }}$ Revision on 22 October 2020

$3^{\text {rd }}$ Revision on 27 October 2020

Accepted on 29 October 2020

\begin{abstract}
Purpose: Establish whether the industry biological asset fair valuing challenges are country-specific or agricultural-sector specific. Determine how the inputs and challenges experienced by the valuers relate to the industry challenges.
\end{abstract}

Research Methodology: Descriptive, qualitative conceptual content analysis of financial reports of 50 listed organizations across 10 countries from 2012 to 2015 ; with relational content analysis through in-person interviews with 24 biological asset valuers.

Results: This paper contradicts prior research as no correlation was identified between large agricultural organizations and the extent of biological asset disclosures. The biological asset valuation and disclosure challenges are not country-specific or agricultural-sectorspecific and the inconsistency in factors applied by the valuers appears to impact the industry challenges directly.

Limitations: As biological assets are only held by agricultural organizations of which not all fair value the assets to report thereon - limiting the number of interviews to 24. Data collected via the interviews represent the challenges and valuation considerations of the individuals and their exposure to biological asset valuations.

Contribution: This research analyzed and categorised the biological asset valuation challenges to determine whether it is country-specific and/or unique to an agricultural sector. The input factors and challenges experienced by the valuers in relation to the reporting challenges allow a relational analysis of the industry challenges.

Keywords: Biological asset valuation, Decision-enhancing disclosures, Fair value accounting, Users of financial statements, Valuation elements

How to cite: Biljon, M. v., Wingard, C. (2020). An agricultural sector assessment of biological asset valuation challenges with inputs considered from valuers. International Journal of Financial, Accounting, and Management, 2(3), 243-258.

\section{Introduction}

Life on earth evolved from hunting and gathering food for the mere survival of the human race, to a modern society indulging in gourmet fresh and processed foodstuffs from pantries. Accomplished through the introduction of farming activities, to cultivate plants and animals, and the expansion thereof into a scientifically-driven agricultural "world". Specialisation is required to produce sustainable production operations, thereby distinguishing the agricultural "world" into agricultural sectors addressing the requirements of the various animals and plants. 
Agricultural products like maize, wheat, soybean, and sunflower are but a few included in the crop production sector. Diverse crops and cultivars are planted in prepared lands at a calculated time to ensure the best yields derived in considering the environmental influencers like rainfall, temperature, and humidity. Knowledgeable decisions are taken on which crop to grow when; when to rehabilitate the land; and how to safeguard the crop against environmental and physical elements to ensure that the controlled asset derives the highest possible value for the owner.

Agricultural processes similarly include the selection of livestock species to best suit the environment. The location of the land, area temperatures, rainfall, humidity, physical terrain, availability and quality of drinking water, medical and sheltering needs, and physical labour requirements for milking and shearing are a few impacting factors on the types of livestock an organisation will hold. Like plants, the livestock is an asset for an organisation as it is held for financial and economic benefit. The plants and livestock will be accounted for and reported on in the financial records of organisations to allow the owners, stakeholders, investors, and other interested users to analyse the business operations, sustainability, and profitability. The International Accounting Standards (IAS) 41 was established to account for these living animals and plants as "biological assets" in the financial reports, and the standard requires them to be valued at a fair value. In the accounting environment, a fair value represents the value of that biological asset if purchased or sold in an open market through an orderly transaction. Fair value accounting principles require the reporters to perform physical valuations on the biological assets. The knowledge, experience, skills, time, effort, and funds required to report biological assets at a fair value resulted in the industry often not reporting on the assets or reporting on it on a different valuation basis.

Prior research established a direct correlation between the organisational size and the extent of fair valued biological asset disclosure. Goncalves and Lopez (2014) confirmed that larger companies have detailed disclosure demands instilled by the users as it implies proper corporate management. Their research follows that of Freedman and Jaggi (2005) who focussed their research on 181 International Financial Reporting Standard (IFRS) compliant organisations and concluded that larger organisations have more activity and therefore require extensive disclosure. Yurniwati, Djunid and Amelia (2018) repeated the research of Goncalves and Lopez on agricultural organisations listed on the Indonesian stock exchange for the 2012 to 2015 financial years to reconfirm a correlation between the size of the organisation with the extent of IAS 41 compliance.

Larger companies might have enhanced biological asset disclosures and might devote more resources to the fair valuing and reporting thereon, yet it was never established whether this conclusion is countryspecific. Nor was the knowledge gap addressed to test whether these larger companies represent a specific category of biological asset - a definite agricultural sector. This research aims to assess: whether biological asset valuation challenges are unique to a certain country and/or agricultural sector? And how does the inputs and challenges experienced by the valuers relate to the industry challenges?

The research includes a consideration of the valuation challenges and factors applied by biological asset valuers to assess whether the prescripts of IAS 41 provide enough guidance to address the industry challenges. Especially as the research aims to determine whether the valuation challenges are unique to a specific country and/or agricultural sector to allow standard setters to assist further.

In the following paragraphs, the literature relating to valuation challenges and fair value accounting of biological assets are discussed. In section 3 the research methodology is addressed, while section 4 deals with the research findings. Section 5 deals with the conclusion and recommendations for further research.

\section{Literature review and hypothesis development}

Accounting standards were developed to detail the requirements of how and when transactions should be recorded (Vukmirovic, Arsenovic, Lalic and Milovanovic, 2012; ASB, 2012; IASB, 2013a; IASB, 2018a). The recording of these transactions and the reporting thereon is regarded as financial accounting. Deegan and Unerman (2011) define financial accounting as a 'process involving the collection and processing of financial information to assist in the making of various decisions by many parties internal and external to the organisation'. Their definition refers to the investors, suppliers, lenders, employees, government, 
customers, and the community as parties interested in the business operations. Consistency in the financial reporting processes of organisations, supported by a uniform valuation and disclosure technique will ensure that financial information can be compared with that of other organisations (Azevedo, 2007; Deegan and Unerman, 2011; Duman, Özpeynirci and Içerli, 2012; Rozentãle and Ore, 2013; Marsh, Austin and Fischer, 2013; Baigrie, 2014; Gonçalves and Lopes, 2015).

Harmonisation of financial reporting in the agricultural sector is driven by Generally Recognised Accounting Practice (GRAP) 27, International Accounting Standard (IAS) 41 and section 34 of the International Financial Reporting Standards (IFRS) for Small and Medium-sized Enterprises (SMEs). GRAP 27 was specifically developed to account for biological assets in the public sector (ASB, 2012). IAS 41 details the prescriptions that are applicable to private enterprises with public accountability, with the IFRS for SMEs available for private sector farmers with no public accountability (IASB, 2009). GRAP 27 and IAS 41 are based on the fair value accounting principles (ASB, 2012; IASB, 2018a), whereas the IFRS for SMEs grants the financial statement compiler an option between fair value accounting and the cost method. The fair value accounting principles are applicable since 1 January 2003 (IAS 41); 1 April 2009 (GRAP) and 9 July 2009 (IFRS for SMEs) respectively (IASB, 2018; ASB, 2012; IASB, 2009). The concept of accounting for biological assets should be well known in the accounting spheres, yet prior research on the implementation and application of the accounting standards confirmed that worldwide it is not consistently applied (Rozentãle and Ore, 2013; Baigrie, 2014).

A study was undertaken on the valuation and reporting practices of beekeeping organisations in Brazil. As beekeeping contributes more than 50 million dollars to the Brazilian economy, the researchers aimed to present a model to measure and disclose the sector activities in terms of their prescribed accounting standard, CPC 29 - the Brazilian IAS 41 equivalent (da Rocha, de Lima Oliveira, Loose and Porto, 2016). Of the four researched beekeepers only one retained data and control over the operations. Two beekeeping organisations merely maintained notebooks while the other maintained no form of data collection. However, none of the researched organisations accounted for or reported any biological assets (the bees) and/or agricultural produce (the honey) in their accounting records (da Rocha et al., 2016). Despite the guidance available in the prescribed accounting standard, effective 2010 in Brazil, the requirements thereof were not adopted and reported on.

The disregard for prescribed accounting standards - including disclosure guidance contained therein - is not unique to the Brazilian beekeepers. Rathnayake and Perera (2016) found that a horticultural grower and exporting company in Sri Lanka neglected to value and report on their single reason for existence: the plants. The total omission from the financial records undervalue the financial position of the company and cause a total misrepresentation to any user of their financial information. As the purpose of financial statements is to provide useful and relevant information to the users thereof (Van Biljon and Scott, 2019) the interested parties cannot assess or evaluate the operations of a horticulture organisation "owning" no biological or bearer assets.

A study by Arbidane and Mietule (2018) confirmed that even though $15 \%$ of Latvia's enterprises are involved in the agricultural sector (in 2016), the principles of IAS 41 has not been applied. Enterprises record and disclose their biological assets as either long-term investments or current assets. Such disclosure does not distinguish between animals and/or plants or the duration of keeping or holding same (Arbidane and Mietule, 2018), therefore not providing any decision-enhancing information to the users of these financial reports.

Apart from organisations totally neglecting the implementation and application of the requirements to report on their fair-valued biological assets, organisations who have done so, do not deliver comparable financial results to allow users to comprehend and analyse the financial results. A study by Elad and Herbohn (2011) demonstrated that those organisations that adopted IAS 41 in Australia, France, and the United Kingdom applied various techniques to value their biological assets. These include net present value (29\%), historic cost $(23 \%)$, fair value (16\%), an independent valuation (13\%), market prices for similar assets (13\%), recent market prices (5\%), and the lower of cost and net realisable value (1\%). 
Baigrie (2014) analysed the application of IAS 41 on the listed South African companies and concluded that only $38 \%$ of listed organisations considered the principles of fair value on adjusted market prices or industry data to value biological assets at the point of harvest. Fifty percent of the listed organisations based their valuations on future cash flows; $6 \%$ applied the cost less accumulated depreciation method and $6 \%$ did not disclose their valuation methods (Baigrie, 2014). The public-sector valuation of biological assets in South Africa is also inconsistent as it is based on the modified cash basis of accounting (50\%), recognition at the point of sale (20\%), accounted as held for sale assets (10\%), expensed (10\%) and fair value (10\%) (Van Biljon, Scott and Wingard, 2013; Scott, Wingard and Van Biljon, 2016).

Prior research further analysed the underlying reasons for organisations producing fair valued biological assets on different valuation bases and contextualised those challenges: Maina (2010) investigated the challenges experienced by SMEs in Kenya to account for biological assets at a fair value. He found that the most significant challenge experienced in valuing is the unavailable market information needed to derive at a fair value. His study is supported by a study performed by Schutte and Buys (2011) on the IFRS for SMEs which concluded that specialised activities like agriculture were of moderate importance to organisations as they are involved in alternative activities and do not necessarily apply fair value accounting on biological assets. These gaps in applied and theoretical knowledge persist, despite the guidance document on IFRS for SMEs, module 34, necessitating the limited organisations that operate with biological assets to apply the principles of fair value accounting to it (IASB, 2009; IASB, 2013b). In circumstances where market information is not available IFRS for SMEs allows for the biological assets to be accounted at cost less accumulated depreciation and impairments, yet the produce should be valued at the unavailable fair valued market information (IASB, 2009; Baigrie, 2014).

Burykin, Klichova, and Bremmers (2011) researched the accounting challenges for SMEs in Russia. Their study found that the information gathered, compiled, and disclosed to comply with IAS 41 is of no use to the Russian users of financial statements, as the principles of IAS 41 and the accounting standards applied in the Russian Federation differ. The study further concluded that the adoption of IAS 41 is not attempted as the substantial costs of implementation exceed the expected economic benefits construed to the organisation (Burykin, et al. 2011; Pike and Chui, 2012; Baigrie, 2014). Consequently, the financial statements of the Russian Federation organisations and those of the European Union cannot be compared, adding to the gap in theoretical knowledge.

Fair valued biological asset reporting in Ghana is affected by the mismatch between financial university training and that required for a professional valuation. The cost of implementing the fair valued reporting requirements; a lack of professional training; and the misalignment between Ghana laws and the reporting requirements signal current challenges experienced (Agyemang, Acheampong and Akenten; 2018).

From the research studies stated earlier, evidently, the lack of market information causes management in all economic sectors to create their individual assumptions and a basis for calculation (Azevedo, 2007; Rozentãle and Ore, 2013; Baigrie, 2014; Leăo and Amborzini, 2014; Gonçalves and Lopes, 2015), especially as IAS 41 provides no guidance on the valuation methods and factors to be considered to derive at fair value (Marsh, et al. 2013). This impairs the comparability of financial information (Baigrie, 2014). The International Accounting Standards Board aimed to address these fair valuing challenges by developing IFRS 13 to guide the valuation of assets in an inactive market (IASB, 2013b; IASB, 2014). As the actual implementation and application of IAS 41 are not limited to fair valuing challenges, studies were undertaken to analyse whether the quantity and value of biological assets held by an organisation might encourage fair valued biological assets.

Research by Goncalves and Lopez (2014) confirmed that the comprehensive disclosure of biological assets is impacted by the concentration of corporate ownership. Their research feeds on prior findings by Freedman and Jaggi (2005) who confirmed that the size of the company is directly linked to the level of information disclosure. This is mainly because larger companies have more activity and therefore require more funding and/or shareholders. Directly linked to the information needs of each user group (Van Biljon and Scott, 2019), larger companies will be compelled to enhance disclosures to demonstrate corporate governance. Yurniwati, Djunia and Amelia (2018) replicated the earlier research conducted by Goncalves 
and Lopez by focusing on more recent financial data. Their study corroborated that the intensity of biological asset holding in a company has significant positive effects on the disclosure of biological assets of listed companies on the Indonesian Stock Exchange (Yurniwati et al., 2018). From these studies, concentrating on larger companies, it cannot be determined whether the industry challenges experienced is unique to a specific country and/or agricultural sector. Considering that larger companies afford comprehensive biological asset disclosures, it is not clear why the fair valuing challenges persist. An analysis of the detailed disclosures on fair valued biological assets by larger organisations may consequently address the knowledge gap on challenges experienced and may offer guidance to similar organisations to overcome same. Therefore, by analysing the detailed biological asset disclosures by larger organisations, and classifying outcomes per country and per agricultural sector, may assist smaller and similar organisations to observe the reporting requirements of IAS 41.

The categorisation of the fair valuing challenges and the financial disclosures per agricultural sector affords an opportunity to obtain contributions from valuers to detail their challenges and guidance to the industry for reflection and to determine their contribution to the industry challenges.

\section{Research methodology}

A total of 50 organisations purposively selected from the stock exchange listings from a total of 10 IFRS compliant countries form the basis of this qualitative, empirical research (PwC, 2014). Preference was given to the BRICS associated countries (5 from Brazil, 4 from Canada, and 11 from South Africa) with the remainder of the sample comprising the countries with the highest agricultural contribution towards the Gross Domestic Product (9 Australian organisations, 9 United Kingdom organisations, 5 from New Zealand and the balance from Netherlands, Italy, Spain and the United States of America). The nature of the organisational operations allowed a classification per main agricultural sector, per country. Content analysis was applied to the annual reports from 2012 to 2015 to conduct a study similar to the research conducted by Yurniwati et al. (2018) on the biological asset disclosures for the same period (2012 to 2015).

As the study analyse the detailed disclosure of the fair valued biological assets, and the informing accounting policies and valuation principles applied, the focus is on the descriptive qualitative data informing the reported value (quantitative data). To establish whether the disclosure requirements of IAS 41 have been met by the researched organisations, the keywords of the reporting standard, the valuation methods, and the themes therein were identified through conceptual analysis. This research method allowed the conceptual analysis results from the financial reports to be used in the relational analysis performed on the interviews conducted with the biological asset valuers to provide an assessment of the industry challenges per agricultural sector. The content analysis allowed the inductive study to evolve from the primary data (financial results) to secondary data (interview feedback) and to corroborate the findings.

The study further contributed to the knowledge bank by analysing the actual valuation factors applied and challenges experienced by 24 biological asset valuers - through interviews and questionnaires. The population comprised financial statement preparers, auditors, various users of the financial information, the accounting standard setter, and agronomists. These interviews and questionnaires were conducted during 2015 and 2016 and assessed the organisational background, valuation calculations, assumptions applied, narrative biological asset description, the applied valuation methods, and unique valuation challenges experienced. The outcome of this analysis is provided to provide guidance to the industry to overcome the researched challenges experienced and to determine the impact of the valuers' inputs on the industry challenges.

\section{Results and discussions}

In analyzing the outcome of the content analysis on the annual (financial) reports, the results from the questionnaires, and the data gathered from the interviews, it is evident that the reporting requirements of IAS 41 is not complied with by larger and listed organizations. This finding contradicts that of similar research conducted by Freedman and Jaggi (2005), Goncalves and Lopez (2014) and Yurniwati et al. (2018) where a direct relationship was identified between the size of the organisation and the detailed financial disclosures provided. To assess whether the biological asset valuation challenges are unique to a certain 
country and/or agricultural sector, the research findings reflect on the classification of biological assets per agricultural sector; the detailed IAS 41 disclosures per country; and the valuation method applied per agricultural sector. The paper further includes direction from industry valuers, to address the challenges experienced in complying with the IAS 41 requirements, with the aim of empowering organizations of all sizes to report on fair valued biological assets.

\subsection{Inconsistent classification of biological assets per agricultural sector}

An analysis of the disclosure of the classification per type of biological asset confirms prior literature that IAS 41 is not implemented uniformly (Van Biljon, 2016). IAS 41 (IASB, 2018a) requires an assessment of, and distinction in the reporting of whether assets are current or non-current to provide decisionenhancing information to users. As demonstrated in Table 1, $18 \%$ of the organisations did not consider the classification requirements of IAS 41 when $6 \%$ reported all activities as inventory and $12 \%$ reporting it as property, plant, and equipment.

Table 1: Percentage of researched organizations disclosing biological assets as either current or noncurrent per agricultural sector

\begin{tabular}{|l|l|l|l|l|l|l|}
\hline $\begin{array}{l}\text { Agricultural } \\
\text { sector/ } \\
\text { classification }\end{array}$ & $\begin{array}{l}\text { "Biological } \\
\text { assets" as a } \\
\text { line item } \\
\text { under } \\
\text { Current } \\
\text { assets }\end{array}$ & $\begin{array}{l}\text { "Biological } \\
\text { assets" as a } \\
\text { line item } \\
\text { under Non- } \\
\text { Current } \\
\text { assets }\end{array}$ & $\begin{array}{l}\text { "Biological } \\
\text { assets" split } \\
\text { \& disclosed } \\
\text { as line items } \\
\text { under both } \\
\text { Current } \\
\text { and Non- } \\
\text { Current } \\
\text { assets }\end{array}$ & $\begin{array}{l}\text { Inventory } \\
\text { reported } \\
\text { (including } \\
\text { biological } \\
\text { assets) }\end{array}$ & $\begin{array}{l}\text { Property, } \\
\text { plant and } \\
\text { equipment } \\
\text { reported } \\
\text { (including } \\
\text { biological } \\
\text { assets) }\end{array}$ & Total \\
\hline Grain & $6 \%$ & $3 \%$ & $6 \%$ & $0 \%$ & $6 \%$ & $21 \%$ \\
\hline Forestry & $0 \%$ & $3 \%$ & $0 \%$ & $0 \%$ & $3 \%$ & $6 \%$ \\
\hline Fruit & $0 \%$ & $0 \%$ & $12 \%$ & $0 \%$ & $0 \%$ & $12 \%$ \\
\hline Grapevines & $0 \%$ & $9 \%$ & $0 \%$ & $0 \%$ & $0 \%$ & $9 \%$ \\
\hline Horticulture & $0 \%$ & $0 \%$ & $3 \%$ & $3 \%$ & $0 \%$ & $6 \%$ \\
\hline Livestock & $6 \%$ & $0 \%$ & $6 \%$ & $0 \%$ & $0 \%$ & $12 \%$ \\
\hline Poultry & $6 \%$ & $0 \%$ & $3 \%$ & $0 \%$ & $0 \%$ & $9 \%$ \\
\hline Sugarcane & $0 \%$ & $6 \%$ & $9 \%$ & $0 \%$ & $3 \%$ & $18 \%$ \\
\hline Vegetables & $0 \%$ & $3 \%$ & $3 \%$ & $3 \%$ & $0 \%$ & $9 \%$ \\
\hline Total & $\mathbf{1 8 \%}$ & $\mathbf{2 4 \%}$ & $\mathbf{4 1 \%}$ & $\mathbf{6 \%}$ & $\mathbf{1 2 \%}$ & $\mathbf{1 0 0 \%}$ \\
\hline
\end{tabular}

Source: Research result (2015)

The classification of the grapevines as non-current assets; the forests as either non-current assets or as part of property, plant and equipment, and with the clear distinction between the current and non-current assets in the fruit industry confirm that these agricultural sectors consider the reporting requirements of IAS 41. As evident from Table 1, there is no reporting consistency in the other agricultural sectors. As users of the financial reports analyse the financial performance and position of organisations in assessing the net worth of current and non-current assets in relation to liabilities the sector results are skewed when relying on information where organisations have no consistency in categorising their biological assets. An assessment of an organisation's ability to generate revenue from non-current and current assets as well as the efficiency and effectiveness of the business operations in relation to inventory holding and turnover will mislead those relying on reported results. 


\subsection{Selected IAS 41 disclosure compliance per researched country}

IAS 41 sets out a biological asset disclosure requirement list. Compliance thereto will provide fair and complete financial information disclosed for users to understand the performance and valuation of the assets. The assessment results as summarised in Table 2 contradicts prior research conclusions that linked the extent of biological asset disclosures to the size of the organisation - especially given that the research sample comprises large agricultural organisations.

Table 2 shows to what extent the researched organisations complied with specific IAS 41 biological asset disclosure requirements - IAS 41 paragraph 40 (IASB, 2018a) requires disclosure of the 'aggregate gain or loss arising during the current period on initial recognition of biological assets and agricultural produce and from the change in fair value less costs to sell of biological assets'. IAS 41, paragraph 41 (IASB, 2018a) requires that organisations detail a description of all groups of biological assets held as either a narrative or quantified note (paragraph 42). The nature of an organisation's activities involving each group of biological assets is to be detailed in the financial reports, supported by the physical quantity of each group of assets held and the actual output of agricultural produce for the reported period (paragraph 46) (IASB, 2018a).

Table 2 highlights that New Zealand was the only researched country where all organisations disclosed the detailed data required in IAS 41. Limited disclosure was provided by organisations in other countries. The United States of America prioritised the disclosure of aggregate fair value gains/losses yet neglected to disclose other required information.

Table 2: Selected IAS 41 disclosures percentage per country

\begin{tabular}{|l|c|c|c|}
\hline Researched country & $\begin{array}{l}\text { IAS 41 } \\
\text { par.40 }\end{array}$ & $\begin{array}{l}\text { IAS 41 } \\
\text { par. 41 }\end{array}$ & $\begin{array}{l}\text { IAS 41 } \\
\text { par.46 }\end{array}$ \\
\hline Australia & $40 \%$ & $100 \%$ & $75 \%$ \\
\hline Brazil & $0 \%$ & $80 \%$ & $40 \%$ \\
\hline Canada & $100 \%$ & $100 \%$ & $100 \%$ \\
\hline New Zealand & $64 \%$ & $91 \%$ & $82 \%$ \\
\hline South Africa & $75 \%$ & $75 \%$ & $75 \%$ \\
\hline United Kingdom & $100 \%$ & $0 \%$ & $0 \%$ \\
\hline United States of America & $\begin{array}{l}\text { Organisations listed as agricultural } \\
\text { traders acting as agents. No biological } \\
\text { assets therefore reported on. }\end{array}$ \\
\hline Netherlands & $\begin{array}{l}\text { Listed agricultural organisations did not } \\
\text { avail any financial data. }\end{array}$ \\
\hline Italy & $\begin{array}{l}\text { Listed agricultural organisations did not } \\
\text { avail any financial data. }\end{array}$ \\
\hline Spain & \multicolumn{4}{l}{} \\
\hline
\end{tabular}

Source: Research result (2015)

The non-disclosure of the aggregate fair value profit or loss may negatively impact on the usefulness of the financial statements as the liquidity and asset ratios are used to inform operational, financial, and investing decisions by users. The fair value change affects the balance of equity and assets. Therefore, the fair valued biological assets might result in more desirable working capital ratios (current assets minus current liabilities); a better current ratio (current assets divided by current liabilities); a distorted return on assets (net income divided by average total assets) and a manipulated debt-equity ratio (total debt divided by equity). Users should be allowed to form decisions on complete, useful, and decision-enhancing information while the industry might be guided on the IAS 41 implementation and compliance. The noncompliance with IAS 41 (paragraph 41) may be considered an intentional mislead of the users of the reports as all organizations have detailed information on what biological assets they hold and manage (IASB, 2018a). 
Table 2 demonstrates that New Zealand organisations all complied with the disclosure requirements. High regard for the disclosure of the nature of and physical quantities of biological assets was demonstrated by South African, Australian, and United Kingdom organisations, yet total compliance lacks.

New Zealand demonstrates a commitment by the financial reporters to consider compliance with the prescribed disclosures of IAS 41, with South Africa, the United Kingdom, and Australia partly achieving compliance. Only $40 \%$ of the BRICS associated Brazil and none of the Canadian companies complies with IAS 41 paragraph 46. The non-disclosure of quantitative information to allow users to comprehend the biological asset value may deter the usefulness of the reports. The users' assessment of the performance of the biological assets, the valuation thereof, the biological transformation and impacted fair value changes may be negatively impacted by such non-disclosure.

\subsection{Valuation methods applied per agricultural sector}

Elaborated information on the valuation method applied may assist users to contextualise the fair valued biological assets. Particularly as not all users of financial statements are accounting orientated, like policymakers, risk managers, owners, and Chief Executive Officers - and the objective of financial reporting is to provide useful information to the users thereof. Table 3 illustrates an assessment of the valuation information disclosed per researched agricultural sector - confirming that despite it not being a formal prescribed requirement, $100 \%$ of the poultry, forests, grapevines, fruit growers, and sugarcane organisations detail additional valuation considerations to enhance the understanding of their valuation methods. The additional information disclosed allows for a user (and guidance seeker) to comprehend the classification and valuation of the bearer and biological assets.

Table 3: Valuation method applied per agricultural sector

\begin{tabular}{|c|c|c|c|}
\hline Agricultural sector & Valuation method applied & $\begin{array}{l}\text { Additional } \\
\text { disclosures }\end{array}$ & Country \\
\hline \multirow[t]{8}{*}{ Livestock } & $\begin{array}{l}\text { Fair value by independent valuers - } \\
50 \%\end{array}$ & \multirow[t]{2}{*}{$\sqrt{ }$} & \multirow{2}{*}{ Australia } \\
\hline & $\begin{array}{l}\text { Fair value based on market prices - } \\
50 \%\end{array}$ & & \\
\hline & Fair value less costs to sell $-100 \%$ & $\sqrt{ }$ & New Zealand \\
\hline & Fair value less costs to sell $-100 \%$ & $\mathrm{x}$ & Canada \\
\hline & Fair value less costs to sell $-50 \%$ & \multirow{2}{*}{$\sqrt{ }$} & \multirow{2}{*}{ New Zealand } \\
\hline & $\begin{array}{l}\text { Fair value based on market prices - } \\
50 \%\end{array}$ & & \\
\hline & Fair value less costs to sell $-100 \%$ & $\sqrt{ }$ & South Africa \\
\hline & Fair value less costs to sell $-100 \%$ & $\sqrt{ }$ & United Kingdom \\
\hline \multirow[t]{2}{*}{ Poultry } & Amortized cost $-100 \%$ & $\sqrt{ }$ & Australia \\
\hline & Fair value less costs to sell $-100 \%$ & $\sqrt{ }$ & South Africa \\
\hline \multirow[t]{4}{*}{ Crop production } & Fair value less costs to sell $-50 \%$ & \multirow{2}{*}{$\sqrt{ }$} & \multirow{2}{*}{ Australia } \\
\hline & $\begin{array}{l}\text { Fair value based on market prices - } \\
50 \%\end{array}$ & & \\
\hline & Fair value less costs to sell $-100 \%$ & $\sqrt{ }$ & Brazil \\
\hline & Fair value less costs to sell $-100 \%$ & $\sqrt{ }$ & South Africa \\
\hline Forestry & Amortized cost $-100 \%$ & $\sqrt{ }$ & Brazil \\
\hline
\end{tabular}




\begin{tabular}{|c|c|c|c|}
\hline Agricultural sector & Valuation method applied & $\begin{array}{l}\text { Additional } \\
\text { disclosures }\end{array}$ & Country \\
\hline & Fair value less costs to sell $-100 \%$ & $\sqrt{ }$ & New Zealand \\
\hline & Fair value less costs to sell $-100 \%$ & $\sqrt{ }$ & South Africa \\
\hline \multirow[t]{4}{*}{ Horticulture } & Fair value less costs to sell $-100 \%$ & $\sqrt{ }$ & Canada \\
\hline & Fair value less costs to sell $-100 \%$ & $\sqrt{ }$ & New Zealand \\
\hline & Not disclosed $-100 \%$ & $\mathrm{x}$ & $\begin{array}{l}\text { United States of } \\
\text { America }\end{array}$ \\
\hline & Inventory valuation $-100 \%$ & $\mathrm{x}$ & Canada \\
\hline \multirow[t]{3}{*}{ Vineyards } & Net present value of cash flows $-100 \%$ & $\sqrt{ }$ & Australia \\
\hline & Fair value less costs to sell $-100 \%$ & $\sqrt{ }$ & New Zealand \\
\hline & Fair value less costs to sell $-100 \%$ & $\sqrt{ }$ & South Africa \\
\hline \multirow[t]{4}{*}{ Fruit trees } & Fair value less costs to sell $-100 \%$ & $\sqrt{ }$ & Brazil \\
\hline & Fair value less costs to sell $-100 \%$ & $\sqrt{ }$ & New Zealand \\
\hline & Fair value less costs to sell $-100 \%$ & $\sqrt{ }$ & South Africa \\
\hline & Fair value less costs to sell $-100 \%$ & $\sqrt{ }$ & United Kingdom \\
\hline \multirow[t]{5}{*}{ Sugarcane } & Fair value less costs to sell $-67 \%$ & \multirow{2}{*}{$\sqrt{ }$} & \multirow{2}{*}{ Brazil } \\
\hline & Net present value of cash flows $-33 \%$ & & \\
\hline & Amortized cost $-100 \%$ & $\sqrt{ }$ & Canada \\
\hline & Fair value less costs to sell $-100 \%$ & $\sqrt{ }$ & South Africa \\
\hline & Fair value less costs to sell $-100 \%$ & $\sqrt{ }$ & United Kingdom \\
\hline
\end{tabular}

Source: Illustration of research result (2015)

Despite an oversight/disregard for the disclosure requirements prescribed in IAS 41, detailed additional disclosures are evident in all researched agricultural sectors. The livestock, cropping and fruit tree sectors are all consistent in the valuation methods applied to report on biological assets held - across all researched countries and organizations. Table 3, however, confirms prior research on the various valuation methods/models applied to report on the biological assets. This research reconfirmed the application of various valuation models specifically on reporting poultry, forestry, horticulture, vineyards, and sugarcane. The application of various valuation bases impairs comparability and distorts the usefulness of financial reports to the users thereof. The interrogation of the preferred valuation method, valuation factors to be applied, and considered in the reporting of the biological assets and the industry challenges experienced by those valuers follow. This is imperative to the theoretical research knowledge as it outlines the valuers' information needs and requirements to deliver on those disclosure requirements detailed in IAS 41, thereby addressing the valuation challenges experienced in the industry. Interestingly, when comparing the underlying data considered by the biological asset valuers to derive at a reportable fair value, there is a disconnect between their information needs and that required to be disclosed per IAS 41. Policymakers may need to consider the user needs and align the reporting principles of the accounting standards to provide meaningful and decision-enhancing information. 


\subsection{Detailed notes to the financial statements}

An analysis of the extent of compliance (number of organizations) with the disclosure requirements of IAS 41 paragraphs 50-53 conclude that New Zealand (100\%) and the South African (82\%) organizations demonstrate a commitment to comply with the Standard whereas the United States of America (25\%) and Canada (19\%) did not include the required biological asset disclosures (the US GAAP requirements are similar to that of IFRS). The disclosure compliance analyzed per agricultural sector in Table 4, revealed that the livestock sector discloses $100 \%$ of the tested data in their financial reports and the fruit and grapevine sectors comply $94 \%$ and $92 \%$ respectively. The poultry sector attains $83 \%$ compliance, sugarcane and forestry $75 \%$ each, horticulture $63 \%$, and the vegetable and crop production achieve $33 \%$ and $36 \%$.

Compliance with the disclosure requirements of IAS 41 can be strengthened in the various agricultural sectors to produce decision-enhancing reports to the users (Van Biljon, 2016).

Table 4 -IAS 41 disclosure compliance percentage per agricultural sector

\begin{tabular}{|l|r|}
\hline Agricultural sector & $\begin{array}{l}\text { Disclosure } \\
\text { requirements } \\
\text { met (\%) }\end{array}$ \\
\hline Forestry & $75 \%$ \\
\hline Fruit & $94 \%$ \\
\hline Grain/Crop & $36 \%$ \\
\hline Grapevines & $92 \%$ \\
\hline Horticulture & $63 \%$ \\
\hline Livestock & $100 \%$ \\
\hline Poultry & $83 \%$ \\
\hline Sugarcane & $75 \%$ \\
\hline Vegetables/Horticulture & $33 \%$ \\
\hline
\end{tabular}

Source: Illustration of research result (2015)

The conceptual content analysis of the biological asset disclosures of the researched organizations contradicts prior research stating that the larger organizations have comprehensive disclosures. This due to the detailed information required by the diverse stakeholders interested in the financial performance and position of the organisation. In analyzing the research results per agricultural sector (section 4.3) and per country (section 4.2), it was established that there is no uniformity in the application of and reporting in terms of IAS 41 - neither per country nor per agricultural sector. The valuation challenges experienced can consequently not be singled to an exact agricultural sector as there is no industry trend assisting by other countries or agricultural sectors to provide solutions. In light of this knowledge gap, the research turned to the biological asset valuers to allow a relational content analysis between their information needs and valuation challenges and that reported on in organizational annual reports.

\subsection{The biological asset valuers' information needs and challenges}

As the listed organisations from IFRS reporting countries did not provide detailed biological asset disclosures in terms of IAS 41, prior research is contradicted claiming that the size of the organisation directly correlates with the extent of disclosures met. The reporting of the research findings per agricultural sector provides clarity on the agricultural sectors prioritising fair value reporting vs. those neglecting same. Prior research concluded on the challenges experienced by the financial reporters on the fair valuing of biological assets. As this research paper aims to bridge the valuation reporting challenges, 24 valuers representing accountants, auditors, owners, managers, government, and specialists - provided guidance on the various factors to be considered in the drive to comply with the IAS 41 requirements. These valuers represent three international accounting firms, a firm based in Canada and 20 South African organisations.

4.5.1 Valuer's preferred method of reporting on biological assets

A survey performed on the researched financial departments reporting on the biological assets concludes that the market value of the biological assets is the preferred valuation method by $40 \%$ of the valuers. The 
market price of similar assets; the use of historical costs and the inventory principles are each preferred by $12 \%$ of the valuers. Limited preference to the use of the most recent market prices; the expected net cash flows; independent valuations by third parties and the application of management assumptions are noted as each was opted for by $6 \%$ of the valuers. With $40 \%$ of the biological asset valuers preferring the market values of the assets, and $12 \%$ preferring the market price of similar assets, a total of $52 \%$ prefer applying the principles of fair value accounting in their valuations. As detailed in section 4.3, the majority of the biological asset valuation methods reported on in, is based on the fair value thereof. Despite the valuation methods applied in the livestock, cropping and fruit tree sectors being the only consistent valuation preference, all sectors demonstrated a consideration of the fair valuing method. Industry challenges can therefore be informed by the individual valuer's valuation preference and not by the application of the fair value principles.

\subsubsection{The role of the valuer and the frequency of valuations}

The research confirmed that valuations are only performed annually by accountants - regardless of the significance of the biological assets in the organisation. Valuations performed by agronomists, irrespective of the significance of the biological assets, lend preference to annual valuation as $33 \%$ acknowledged the importance of monthly valuations. As agronomists are directly involved in the biological transformation of the assets, they are equipped with the knowledge and technical expertise to provide meaningful insight into the valuations. Frequent valuations may benefit the organizations and consideration can be given to allow these experts to perform valuations in conjunction with the accountants to expose the latter to the technical aspects of the intricate assets.

Owners are not actively involved in the valuation of biological assets and prefer annual valuations. Management prefers annual valuations (67\%) while despite the significance of the biological asset holding, monthly valuations are performed by the $29 \%$ organisations where the production departments perform the valuations. The further assessment finds that no valuation challenges are experienced by the organisations that opt for monthly valuations. An analysis of their valuations reveals that their valuation success lies in the fact that they consider all the valuation factors as per Table 5. An assessment of the consideration of these factors by the other valuers confirms that their valuations might be enhanced, and their challenges are addressed when these factors are considered.

Table 5: Significance of valuation factors considered by biological asset valuers

\begin{tabular}{|l|c|c|c|c|c|c|}
\hline & \multicolumn{5}{|c|}{ Vrequency of consideration given to valuation factors } \\
\cline { 2 - 7 } & $\begin{array}{l}\text { Always } \\
\mathbf{9 0 \%} \\
\mathbf{1 0 0 \%}\end{array}$ & $\begin{array}{l}\text { Seldom } \\
\mathbf{5 1 \%} \\
\mathbf{8 9 \%}\end{array}$ & $\begin{array}{l}\text { Selectively } \\
\mathbf{1 1 \%}-\mathbf{5 0 \%}\end{array}$ & $\begin{array}{l}\text { Exceptions } \\
\mathbf{5 \%} \mathbf{- 1 0 \%}\end{array}$ & $\begin{array}{l}\text { Almost } \\
\text { never } \\
>\mathbf{5 \%}\end{array}$ & $\begin{array}{l}\text { Never } \\
\mathbf{0 \%}\end{array}$ \\
\hline Age of animal/plant & $88 \%$ & $0 \%$ & $12 \%$ & $0 \%$ & $0 \%$ & $0 \%$ \\
\hline $\begin{array}{l}\text { The location of the } \\
\text { animal/plant }\end{array}$ & $47 \%$ & $24 \%$ & $0 \%$ & $0 \%$ & $12 \%$ & $17 \%$ \\
\hline $\begin{array}{l}\text { The condition of the } \\
\text { animal/plant }\end{array}$ & $76 \%$ & $0 \%$ & $12 \%$ & $6 \%$ & $0 \%$ & $6 \%$ \\
\hline $\begin{array}{l}\text { The expected economic } \\
\text { benefits to be derived from the } \\
\text { animal/plant }\end{array}$ & $76 \%$ & $0 \%$ & $12 \%$ & $0 \%$ & $6 \%$ & $6 \%$ \\
\hline $\begin{array}{l}\text { The expected cash flow to be } \\
\text { generated from the } \\
\text { animal/plant }\end{array}$ & $64 \%$ & $0 \%$ & $6 \%$ & $0 \%$ & $6 \%$ & $24 \%$ \\
\hline $\begin{array}{l}\text { The expected yield to be } \\
\text { harvested }\end{array}$ & $70 \%$ & $6 \%$ & $6 \%$ & $6 \%$ & $0 \%$ & $12 \%$ \\
\hline $\begin{array}{l}\text { The costs to sell the } \\
\text { animal/plant }\end{array}$ & $88 \%$ & $0 \%$ & $6 \%$ & $0 \%$ & $0 \%$ & $6 \%$ \\
\hline The quality of the animal/plant & & & & & & $0 \%$ \\
\hline
\end{tabular}




\begin{tabular}{|l|c|c|c|c|c|c|}
\hline \multirow{2}{*}{ Valuation factors } & \multicolumn{6}{|l|}{ Frequency of consideration given to valuation factors } \\
\cline { 2 - 7 } & $\begin{array}{l}\text { Always } \\
\mathbf{9 0 \%} \\
\mathbf{1 0 0 \%}\end{array}$ & $\begin{array}{l}\text { Seldom } \\
\mathbf{5 1 \%}-\mathbf{8 9 \%}\end{array}$ & $\begin{array}{l}\text { Selectively } \\
\mathbf{1 1 \%}-\mathbf{5 0 \%}\end{array}$ & $\begin{array}{l}\text { Exceptions } \\
\mathbf{5 \%} \mathbf{- 1 0 \%}\end{array}$ & $\begin{array}{l}\text { Almost } \\
\text { never } \\
\mathbf{5 \%}\end{array}$ & $\begin{array}{l}\text { Never } \\
\mathbf{0 \%}\end{array}$ \\
\hline $\begin{array}{l}\text { The market price of the } \\
\text { animal/plant }\end{array}$ & $64 \%$ & $0 \%$ & $18 \%$ & $0 \%$ & $6 \%$ & $12 \%$ \\
\hline $\begin{array}{l}\text { The sector prices of the } \\
\text { specific animal/plant }\end{array}$ & $70 \%$ & $0 \%$ & $12 \%$ & $0 \%$ & $6 \%$ & $12 \%$ \\
\hline $\begin{array}{l}\text { The inputs from management } \\
\text { on how to value the } \\
\text { animal/plant }\end{array}$ & $58 \%$ & $0 \%$ & $12 \%$ & $0 \%$ & $6 \%$ & $24 \%$ \\
\hline The expected harvesting date & & & & & & \\
\hline
\end{tabular}

Source: Research result (2016)

Fair value accounting specifically requires the location, condition, and costs to sell biological assets to be considered in the valuation thereof (IASB, 2018b). Only 47\% of organisations consider the location of the biological asset, $76 \%$ consider the condition thereof and $70 \%$ consider the costs to sell the assets in their valuation.

As IAS 41 is an Accounting Standard prescribing the information to be disclosed on financial reports, an expectation is that accountants would consult the standard and ensure that the requirements are met when he/she is responsible for the biological asset valuation. However, from the sample of five accountants consulted in this research, only one considers the actual condition of the assets. The costs to sell the assets are not considered by two of the five valuers. Three of the organisations consider inputs from management and other stakeholders in their valuation process, confirming that accountants may merely value biological assets for financial statement purposes and not necessarily to produce useful information on the performance thereof. It was noted that the respondents who do not experience valuation challenges considered all listed valuation factors and performed monthly valuations viz. a valuation team. The recommendation by the production organisations where inputs are provided by various experts in the field may thus address the biological asset valuation challenges experienced in the industry (Van Biljon, 2016).

\subsubsection{Challenges experienced by the biological asset valuers}

A survey to identify the industry challenges experienced by biological asset valuers, conclude that $29 \%$ of the respondents do not experience any valuation challenges. Their success is due to the execution of monthly valuations and the collaboration between informed individuals to form a valuation team. They also consider all the informing factors as detailed in Table 5. As indicated in Figure 1 the major valuation challenge (41\%) experienced by the respondents is the significant cost-related thereto. In addition, 35\% of the respondents experience a lack of understanding of the prescribed valuation model while $24 \%$ find the measurement of the age and the condition of the biological assets problematic. 
Figure 1: Challenges experienced to value biological assets

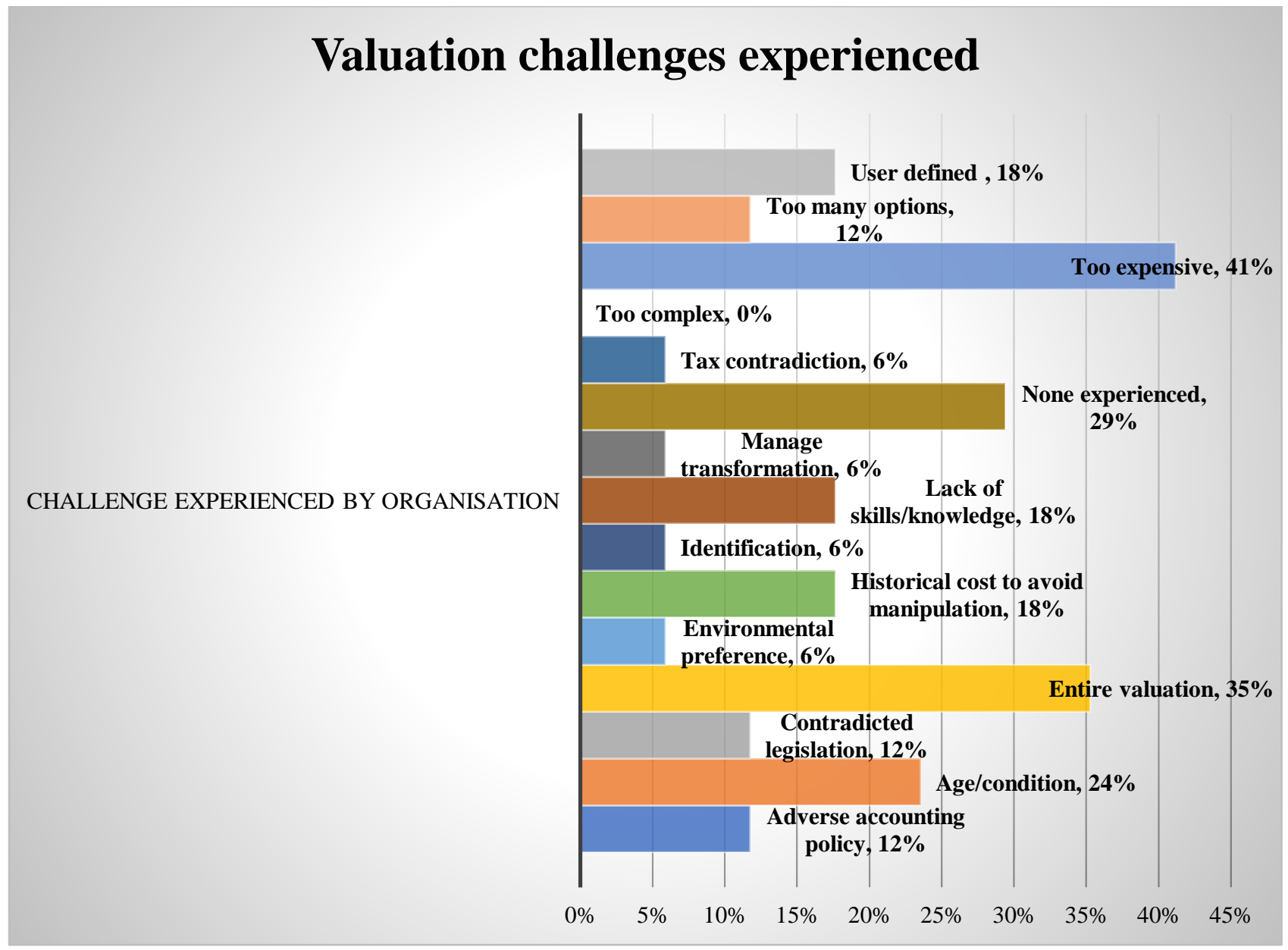

Source: Research result (2016)

The valuers are further challenged by the users of their reports informing the actual valuations (18\%); fair value accounting exposing the valuers to a manipulation risk (18\%); their accounting policies prescribe historical cost to be used in the valuation as a manner to avoid manipulation altogether (18\%) and a lack of valuation expertise (18\%). In assessing the valuation challenges experienced in relation to the frequency of valuations performed, it was noted that $67 \%$ of the valuers perform annual valuations with an average of $67 \%$ of the valuation factors per Table 4 being considered.

From the assessed valuation challenges, it is concluded that frequent valuations of biological assets enhance the required skills and experience to assist in the valuation process and that inputs on all the valuation factors should be obtained from the various stakeholders to assist in the financial calculations - reducing the actual valuation costs and ensuring compliance with the fair value principles of IAS 41 .

\section{Conclusion}

Prior research established a direct correlation between the extent of fair valued biological asset disclosures and the organizational size; especially as larger organizations have increased qualitative and quantitative information demands by users. In replicating prior research on the same period (2012 to 2015), this research contradicts the prior findings as the agricultural listed organizations from IFRS compliant countries did not consider all IAS 41 disclosure requirements - being the United States of America, Canada, and Brazil.

IAS 41 aims to guide financial reporters and biological asset valuers to provide complete and comparable results in the industry. A consideration of the disclosure requirements therein would therefore guide reporters to provide meaningful and decision-enhancing information to the users thereof. From the literature 
review, it is evident that reporting the biological assets in terms of IAS 41 did not result in comparable financial statements and that significant industry challenges and discrepancies exist. As these reporting challenges have not been analyzed per agricultural sector and/or per country in prior research, this study incorporated such analysis. The aim of determining whether fair valued biological asset valuations are either country-specific or agricultural-sector-specific could allow for organizations to gain knowledge and assistance from others to address the unique challenges experienced. However, in analyzing the research results further per agricultural sector, the grain, horticulture, livestock, poultry, sugarcane, and vegetable sectors did not distinguish biological assets as either current or non-current as required in the accounting standards. Detailed IAS 41 disclosures were lacking in the vegetable and grain industries where $33 \%$ and $36 \%$ compliance were identified respectively - confirming that listed agricultural organizations are not necessarily devoted to providing useful information to their stakeholders. Further analysis of the valuation methods applied per agricultural sector revealed inconsistent valuation methods applied in the poultry, forestry, horticulture, vineyards and sugarcane sectors. Neither country-specific nor agricultural specific industry trends exist to provide guidance to other countries and agricultural sectors to enhance the fair value reporting on biological assets.

The research turned to the biological asset valuers to correlate the lack of IAS 41 compliance to either a gap in the accounting standard or to the valuers themselves. The actual valuation factors considered by these biological asset valuers revealed that the disclosure requirements of IAS 41 do not necessarily address valuation detail as it only focuses on information pertaining to the location, condition, and cost to sell the assets. With only $46 \%$ of the valuers considering the location of the assets, $76 \%$ considering the condition, and only $70 \%$ considering the cost to sell it in their valuations, it is evident that guidance provided in IAS 41 is either not considered relevant to the valuations, or ignored. In assessing the valuation method applied by the valuers only $40 \%$ opted to apply market values as recommended in IAS 41 .

The valuation challenges experienced by these valuers were assessed against the frequency of their valuations and the skills applied therein. Where business owners, managers, accountants, and auditors were responsible for the biological asset valuations, no consultative process existed in the annual valuations they opted for - questioning whether it was merely performed for annual reporting purposes. Agronomists however formed a valuation team, consulting various stakeholders for inputs in their monthly valuation of the biological assets to actively manage it. The valuation challenges experienced per industry could therefore be a result of whether such sector requires the use of specialists, like agronomists, to actively manage and value the biological assets, which can be explored through further research. Relational analysis of the assessment of the organizational devotion to compliance with IAS 41 and the disconnect between the valuers' inputs however reflects that industry challenges may be a result of the preferences of the valuers and not by the lack of guidance in IAS 41 .

\section{Limitation and study forward}

Interviews conducted in this research was limited to 24 biological asset valuers, as these assets are only held by agricultural organizations, while not all report on the assets. The biological asset valuing and the reporting thereon is therefore confined to agricultural sectors and not considered by other trading organizations. The interviews conducted were considered adequate to corroborate the foregoing results of the conceptual qualitative content analysis. This research method was considered the best suitable to analyze the biological asset valuations per agricultural sector, as the narrative information and accounting policies applied does not allow a quantitative research method to be applied. Content analysis also allowed the conceptual analysis of the annual reports to be corroborated through relational content analysis from the interview outcomes.

This study did not consider the 2016 amendment to IAS 41 classifying bearer biological assets as part of Property, Plant and Equipment as it considered financial reports for the periods 2012 to 2015. This disclosure amendment opens the door for a replication of this research on listed organizations with the classification of the bearer assets as property, plant and equipment and not as part of biological assets, especially with a focus on the disclosures per agricultural sector. 


\section{Acknowledgement}

The valuable inputs received from all the research participants in this study is greatly appreciated.

\section{References}

Accounting Standards Board (ASB). (2012). Generally Recognised Accounting Practice (GRAP) 27 Agriculture. http://www.asb.co.za/documents/standards. Accessed 1 August 2020.

Agyemang, J.K., Acheampong, O. and Akenten, W.N. (2018). Fair value accounting: Implementation challenges facing Small and Medium-sized entities in the agricultural sector. International Journal of Accounting and Financial Reporting, 60-81.

Arbidane, I. and Mietule, I. (2018). Problems and solutions of accounting and evaluation of biological assets in Latvia. Entrepreneurship and Sustainability Issues, 10-22.

Azevedo, G.M.C. (2007). Dimension of the company versus knowledge of IAS 41, Instituto Superior de Contabilidade e Administração da Universidade de Aveiro. https://papers.ssrn.com/sol3/papers.cfm?abstract_id=975510. Accessed 3 August 2020.

Baigrie, I. (2014). An analysis of the financial reporting compliance of South Africa public agricultural companies. Journal of Economic and Financial Sciences, 833-853.

Burykin, Y. Klichova, G. and Bremmers, H. (2011). The development of integrated accounting in small and medium-sized companies in the agri-and food sector of the Russian Federation. Agro inform Publishing House, 131-135.

Da Rocha, S.A., de Lima Oliveira, D., Loose, C.E. and Porto, W.S. (2016). Measurement and disclosure of the bearer biological asset at the fair value in beekeeping: an alternative to the historical cost. Custos e@ gronegócio on line, 273-302.

Deegan, C. and Unerman, J. (2011). Financial accounting theory. Second edition. Berkshire: McGrawHill.

Duman, H., Özpeynirci, R. and Içerli, M. (2012). Agricultural activities - TAS 41: Turkey example. International journal of academic research in accounting, finance and management sciences, 118131.

Elad, C. and Herbohn, K. (2011). Implementing fair value accounting in the agricultural sector. The Institute of Chartered Accountants of Scotland.

Freedman, M. and B. Jaggi. (2005). Global warming, commitment to the Kyoto Protocol, and accounting disclosures by the largest global public firms from polluting industries. The International Journal of Accounting, 15-232.

Goncalves, R. and Lopes, P. (2014). Determinants of agricultural firm-specific financial reporting. University of Porto, 470-481.

Gonçalves, R. and Lopes, P. (2015). Value-relevance of biological assets under IFRS: FEP working papers 556. https://ideas.repec.org/p/por/fepwps/556.html. Accessed 4 June 2020.

International Accounting Standards Board (IASB). (2013a). Discussion paper DP/2013/1: A review of the conceptual framework for financial reporting. http://archive.ifrs.org/Current-Projects/IASBProjects/Conceptual-Framework/Discussion-Paper-July-2013. Accessed 19 October 2020.

International Accounting Standards Board (IASB). (2013b). International Financial Reporting Standards (IRFS) 13: Fair value measurement. http://eifrs.ifrs.org/eifrs/bnstandards/en/IFRS13.pdf. Accessed 4 June 2020.

International Accounting Standards Board (IASB). (2018a). International Accounting Standards (IAS) 41 Agriculture. http://eifrs.ifrs.org/eifrs/bnstandards/en/IAS41.pdf. Accessed 2 August 2020.

International Accounting Standards Board (IASB). (2018b). International Financial Reporting Standards (IRFS) 13 Fair value measurement. http://www.ifrs.org/IFRSs/IFRS.htm. Accessed 9 May 2018.

International Accounting Standards Board (IASB). (2014). Technical summary: IFRS 13 Fair value measurement. https://www.ifrs.org/projects/2011/fair-value-measurement. Accessed 3 June 2020.

International Accounting Standards Board (IASB). (2009). International Financial Reporting Standard (IFRS) for small and medium-sized entities (SMEs). http://eifrs.ifrs.org/eifrs/sme/en/IFRSforSMEs2009.pdf. Accessed 4 June 2020.

Maina, P.N. (2010). Fair value reporting challenges facing small and medium-sized entities in the agricultural 
http://uir.unisa.ac.za/bitstream/handle/10500/4093/dissertation_maina_p.pdf?sequence=1. Accessed 4 June 2020.

Marsh, R., Austin, S.F. and Fischer, M. (2013). Accounting for agriculture products: US versus IFRS GAAP. Journal of business \& economic research, 79-88.

Pike, B. and Chui, L. (2012). An evaluation of the FASB's conceptual framework from a user's perspective. Academy of Accounting and Financial Studies Journal, 77-94.

PricewaterhouseCoopers (PwC). (2014). IFRS adoption by country. http://www.pwc.com/us/en/issues/ifrsreporting/publications/ifrs-status-country.jhtml. Accessed 2 December 2014.

Rathnayake, N.O.P. and Perera, H.A.P.L. (2016). Recognition of Bearer Plants under Biological Asset or PPE. Case Studies in Accounting "Bridging the Gap". University of Kelaniya.

Rozentãle, S. and Ore, M. (2013). Evaluation of biological assets: problems and solutions. Journal of modern accounting and auditing, 57-67.

Schutte, D. and Buys, P. (2011). A critical analysis of the contents of the IFRS for SMEs - A South African perspective. South African Journal of Economic and Management Sciences, 188-209.

Scott, D., Wingard, H.C. and Van Biljon, M. (2016). Challenges with the financial reporting of biological assets by Public Entities in South Africa. South African Journal of Economic and Management Sciences, 139-149.

Van Biljon, M. (2016). An application guideline for the fair value accounting of biological assets. http://oasis.unisa.ac.za/record=b2643229 S1.

Van Biljon, M. and Scott, D. (2019). The importance of biological asset disclosures to the relevant user groups. https://doi.org/10.1080/03031853.2019.1570285.

Van Biljon, M., Scott, D. and Wingard, H.C. (2013). Challenges with the financial reporting of biological assets in a public entity: proceedings of the 2013 SAAA Biennial Conference.

Vukmirovic, N., Arsenovic, D., Lalic, S. and Milovanovic, D. (2012). Evaluation of accounting acquisition of biological assets and property. Third international scientific symposium, Agrosym Jahorina, 723727.

Yurniwati, Y., Djunid, A. and Amelia, F. (2018). Effect of Biological Asset Intensity, Company Size, Ownership Concentration, and Type Firm against Biological Assets. The Indonesian Journal of Accounting Research, 121-146. 